\title{
Postvention in action. The international handbook of suicide bereavement support
}

\author{
Anmeldt av Kim Larsen
}

POSTVENTION-BEGREPET I denne bokens tittel ble først lansert av en av grunnleggerne av moderne suicidologi, Edwin Shneidman (1918-2009), på siste halvdel av 196o-tallet. Han forklarer bredden av tiltak mot selvmord som følger:

«I would like to use the Latin root vention, using three prefixes to portray the full range of activity. I would like to suggest prevention, intervention and postvention ... In postvention, one deals with people after suicide attempts and with the survivor-victims of committed suicide» (s. 102. Uthevinger i originalen).

Shneidman beskriver noen år senere, i forordet til Albert Cains bok Survivors of suicide (1972), etterlattes situasjon slik:

«I believe the person who commits suicide puts his psychological skeleton in the survivor's emotional closet - he sentences the survivor to deal with many negative feelings and, more, to become obsessed with thoughts regarding his own actual or possible role in having precipitated the suicidal act or failed to abort it. It can be a heavy load» (s. x).
Både det at selvmord i vår kultur helt siden antikken har vært omfattet av et betydelig stigma, og det at selvmord er en valgt handling og inntreffer brått, tilsier at sorgen etter selvmord kan ha spesielle elementer i forhold til

\section{Suicidologien er i seg selv en relativt ny vitenskap hvor forskning om etter- latte har vært det sist utviklede området.}

annen type dødsfall, også annen type brå død. Til tross for disse åpenbare påkjenningene er systematisk forskning om tiltak for etterlatte etter selvmord ikke eldre enn ca. 50 år, hvor mesteparten av forskningen har vært utført de siste 20 år. Heldigvis er det i dag en bred oppfatning av viktigheten av tiltak etter selvmord, også på den måten at «... postvention ....can be viewed as ... suicide prevention» i lys av de påkjenninger etterlatte kan oppleve (Andriessen, 2009, s. 43).

Suicidologien er i seg selv en relativt ny vitenskap hvor forsk- ning om etterlatte har vært det sist utviklede området. Bidragyterne i kapittel 26 beskriver situasionen slik: "The vast majority of research in suicidology has focussed on the causes of suicide, and to a much lesser extent, on the treatments for suicidal individuals. The field had barely begun to study suicide loss survivors as an at-risk population, and to develop a solid empirical base for postvention efforts with survivors» (s. 288). Det finnes en god del litteratur om etterlatte, men mye av denne litteraturen har vært skrevet ut fra egne opplevelser og har derfor vært av subjektiv og usystematisk karakter. Heldigvis har vi de senere årene også fått mer forskningsbasert litteratur, delvis som følge av at mange land har fått formaliserte og politisk forankrede tiltaksplaner mot selvmord. Fra praksis er det kommet tallrike beskrivelser av konkrete tiltak for etterlatte; de fleste av dem gruppebaserte. I akademia har det blitt utfort en god del forskning samtidig som interessen rundt komplisert sorg har bidratt til å sette forskning på etterlatte etter selvmord på agendaen i større grad. Samlet sett har imidlertid feltet båret preg av å bestå av mange og til dels 


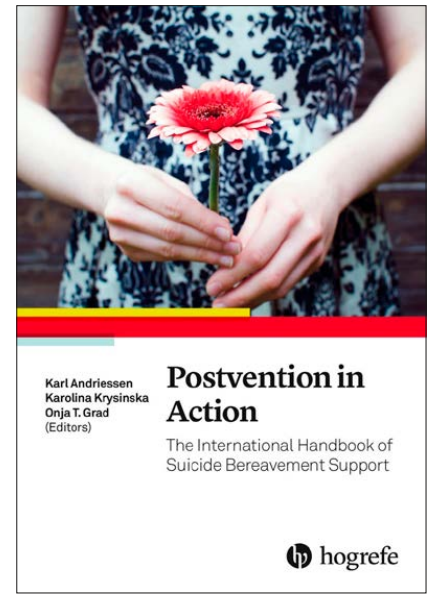

KARL ANDRIESSEN, K., KRYSINSKA, K. \& GRAD, O.T. (RED.):

Postvention in action. The international

handbook of suicide bereavement

support.

Göttingen: Hogrefe. 2017

ISBN: 978-0-888937-493-5

423 sider motstridende perspektiver av både akademisk og selvopplevet karakter som ikke har vært integrert med hverandre. Kan den foreliggende bok bidra til høyere grad av integrasion på dette viktige feltet?

La oss se hva vi kan finne. I del 1, «Current knowledge and implications for support» (s. 1-85), oppsummeres kunnskapsgrunnlaget om den risiko etterlatte etter selvmord kan ha for både fysiske og psykiske symptomer, og hvilke faktorer som er funnet å føre til en best mulig salutogen bearbeiding av påkjenningene; forskjellige former for posttraumatisk vekst og søken etter mening. Del 1 inneholder også ett kapittel om ungdom som etterlatte etter selvmord og om kiønnsforskjeller i opplevelse av sorg og hvordan en sørger. I del 2, "Suicide bereavement support in different settings» (s. 101-212), fremstilles den historiske utviklingen av tiltak overfor etterlatte igangsatt av etterlatte selv og forholdet mellom disse og suicidologien som vitenskapelig disiplin. Vi får et kapittel om forskning på effekten av forskjellige tiltak og et kapittel om mulige farer og potensielt negative effekter ved tiltakene. Deretter følger eksempler på postvention innenfor forskjellige arenaer; allmennpraksis, rettsmedisin, arbeidsplassen, og nettbaserte tiltak. Del 2 inneholder også et kapittel om religion og spiritualitet og et kapittel om kunstneriske uttrykksformer i bearbeidingen av sorgen etter selvmord. Del 3, «Suicide bereavement support in different populations» (s. 225-255), som er bokens korteste del, starter med et kapittel om tiltak etter selvmordsclustere og mord-selvmord. Deretter følger et kapittel om hvordan mangel på tillit overfor helsevesenet kan påvirke forløpet til sorgen etter selvmord. En slik mangel på tillit kan oppstå ved at det faktum at selvmordet har skjedd på en måte «beviser» at helsevesenet ikke kunne hjelpe, eller at det har vært uheldige erfaringer med helsevesenet i forkant av selvmordet. Deretter følger et kapittel om et, etter mitt skjønn, underfokusert tema; profesionelles reaksion på selvmord hos pasienter. Profesionelle blir i denne sammenheng også etterlatte, som både har fellestrekk med andre etterlatte når det gjelder reaksjoner, og også berøres av særpregede tema i egenskap av at de er profesionelle (formell granskning av Helsetilsynet, syndebukkpros- esser i organisasjonen, etc). Denne delen avsluttes med et kapittel om tiltak etter selvmord hos urfolk i Kanada. Bokens fjerde og siste del er også dens lengste og heter «Help for the bereaved by suicide in different countries» (s. 271-411), og vi får her korte presentasioner av tiltak for etterlatte i forskjellige land. Tyngdepunktet ligger ikke uventet på USA og land i Europa.

Som det fremgår av beskrivelsen er dette en mangefasettert bok som tar opp postvention, tiltak etter selvmord, i hele sin bredde. En tilsvarende bredde er også intendert for lesernes vedkommende, idet boken er beregnet på «clinicians and researchers, as well as for support group faciliators and survivors involved in community activities» (s. xv). Med en slik breddeorientering både når det gielder tema og lesere, og med en bok som i lys av dette ikke er på mer enn litt over 400 sider, kunne en mistenke at redaktørene ville sett seg nødt til å prioritere bredde på bekostning av dybde slik at stoffet ble for overfladisk. Ut fra disse rammebetingelsene er de kommet svært godt i havn. Boken gir en panoramisk oversikt, men klarer samtidig å ivareta dybden i de faglige drøftin- 
gene og i nyansene ved formidling av empiriske resultater på en tilfredsstillende måte.

Redaktørene har basert boken på en vitenskapelig tilnærming, ikke slik at den blir verdensfjern; vi får jevnlige vignetter som illustrerer både forskningsfunn og tiltak. På denne måten blir det selvopplevde satt inn i en større sammenheng. En del av den litteraturen om etterlatte som jeg har lest har vært skjemmet av to faktorer. Den første og viktigste har vært en tendens til absolutisme og universalisme ved å giøre egne erfaringer allmenngyldige («det som var løsningen for meg er løsningen for alle andre også»/»jeg har opplevet det så jeg vet hva jeg snakker om», etc). Noen ganger kan en også se en ganske antagonistisk og endog militant holdning til psykiatrien og til profesjonelle hielpere. Begge disse momentene hemmer feltet fordi de lukker dialogen. På denne bakgrunn oppleves den foreliggende bok som en befrielse. Boken er basert på teori og forskning, hvor metodeproblemer diskuteres underveis og alternative tolkninger av funn drøftes, og hvor etterlattes erfaringer er satt inn i et teoretisk og forskningsmessig rammeverk.
Siden temaet postvention er så nytt og det mangler forskning på mange områder, bidrar boken til å identifisere viktige forskningsspørsmål i tiden fremover. Det er også sympatisk at potensielt negative effekter av tiltakene fordomsfritt diskuteres (uheldige gruppeprossesser som kan giøre vondt verre med en ensidig fokusering på dysforiske emosjoner, etc.). Tiltak som kan fungere hensiktsmessig i en kontekst kan ha uheldige effekter i en annen. Gjennomgående er det en høy standard på kapitlene, men det er også uunngåelig at bidragene i en så omfattende og bredspektret bok som dette vil måtte variere en del i kvalitet, noe som også er tilfelle her. Siste del inneholder også uvegerlig en del gientakelser ved at ganske like tiltak repeterende blir beskrevet. Denne delen kunne med fordel vært bedre koordinert og strammere redigert.

Med sin bredde og vitenskapelige tilnærming fyller boken en viktig nisje i litteraturen om postvention, tiltak etter selvmord. Å lese den ga en følelse av at «brikkene falt på plass» ved at de konkrete tiltakene ble satt inn i en overliggende suicidologisk sammenheng. Postvention in action.
The international handbook of suicide bereavement support må kunne kalles en internasjonal begivenhet på postvention-feltet. Boken er uvurderlig både slik den formidler kunnskap på en vitenskapelig og balansert måte og slik den identifiserer problemstillinger for fremtidig forskning.

\section{REFERANSELISTE:}

Andriessen, K. (2009). Can postvention be prevention? Crisis, 30, 43-47.

Shneidman, E.S. (1972). Foreword. I Albert C Cain (Red.): Survivors of suicide. Springfield: Charles C. Thomas. S. ix-xi. 